University of Nebraska - Lincoln

DigitalCommons@University of Nebraska - Lincoln

Faculty Papers and Publications in Animal

Science

Animal Science Department

2006

\title{
Application of the 1996 NRC to Protein and Energy Nutrition of Range Cattle
}

H. H. Patterson

South Dakota State University

D. C. Adams

University of Nebraska, North Platte, dadams1@unl.edu

T. J. Klopfenstein

University of Nebraska-Lincoln, tklopfenstein1@unl.edu

G. P. Lardy

North Dakota State University, Fargo

Follow this and additional works at: https://digitalcommons.unl.edu/animalscifacpub

Part of the Animal Sciences Commons

Patterson, H. H.; Adams, D. C.; Klopfenstein, T. J.; and Lardy, G. P., "Application of the 1996 NRC to Protein and Energy Nutrition of Range Cattle" (2006). Faculty Papers and Publications in Animal Science. 775.

https://digitalcommons.unl.edu/animalscifacpub/775

This Article is brought to you for free and open access by the Animal Science Department at DigitalCommons@University of Nebraska - Lincoln. It has been accepted for inclusion in Faculty Papers and Publications in Animal Science by an authorized administrator of DigitalCommons@University of Nebraska - Lincoln. 


\title{
$\sqrt{17 \pi}$ \\ A pplication of the 1996 NRC to Protein and Energy Nutrition of Range Cattle
}

\author{
H. H. PATTERSON, ${ }^{* 2}$ D. C. ADAMS, ${ }^{\dagger}$ T. J. KLOPFENSTEIN, ${ }^{\ddagger}$ and G. P. LARDY $\$$ \\ *South Dakota State University, Department of Animal and Range Sciences, Brookings 57007; \\ †University of Nebraska, West Central Research and Extension Center, North Platte 69102; \\ "Department of Animal Science, University of Nebraska, Lincoln 68583; and ${ }^{\S}$ Department of Animal \\ and Range Science, North Dakota State University, Fargo 58105
}

\section{Abstract}

Based on applications of the $1996 \mathrm{Na}$ tional Research Council (NRC) Nutrient Requirement of Beef Cattle (2000 update) model at our laboratories and on use of the model to evaluate published literature, it is our assessment that the NRC model (Level 1) represents an advancement in nutrient requirements of grazing cattle. We evaluated 8 published studies (35 treatment observations) to compare observed changes in body condition score (BCS) to those predicted by the $N R C$ model, and to develop criteria to help with application of the model to range cattle nutrition. When in vitro organic matter disappearance (IVOMD) of grazed diets was converted to $D E[D E=$ $(1.07 \times I V O M D)-8.13]$ and used as a proxy for TDN, there were no differences in observed vs. predicted BCS change $(P=0.44)$. A critical component of the 1996 NRC model is the incorporation of the metabolizable protein system. An accurate estimate of microbial efficiency is key to application of the metabolizable

\footnotetext{
${ }^{1} \mathrm{~A}$ contribution of the Univeristy of $\mathrm{Ne}$ braska Agricultural Research Division, Lincoln, NE 68583. J. Series. No. 14224.

${ }^{2}$ To whom correspondence should be addressed: trey@padlockranch.com
}

protein system. We propose the use of an equation to adjust microbial efficiency for diets less that $65 \%$ TDN. The NRC model should be applied to 30-d time intervals if animal requirements or forage quality are changing rapidly. Accurate inputs for stage of gestation, days into lactation, breed, milk production, dietary TDN, and microbial efficiency are necessary for the model to yield accurate results. Work is needed to define and model microbial efficiency, nitrogen recycling, and the quality of diets selected by grazing livestock in various environments.

Key words: metabolizable protein; National Research Council, cattle, range

\section{Introduction}

In 1996 the National Research Council (NRC) published the seventh edition of the Nutrient Requirements of Beef Cattle (NRC, 1996), which included a computer model to generate requirements and evaluate rations (1996 NRC model). The computer software allows nutrient modeling using both empirical (Level 1) and mechanistic (Level 2) methods. The scope of the discussion in this paper is limited to application of Level 1 of the NRC model (2000 update). Level
1 is similar to previous publications (NRC, 1984) in use of tabular values for the nutrient content of feedstuffs, but the model has added predictive functions to increase the accuracy of animal requirement and intake predictions. These predictive functions are only as good as the user inputs. It is important that model users understand the appropriate inputs into the NRC model, including animal inputs, energy values, the activity feature, environmental adjustments, and modeling periods. In addition, there is need to understand the accuracy of energy intake predictions and nutrient balance estimates generated by the 1996 NRC model. The NRC adopted the use of a metabolizable protein (MP) system (NRC, 1996). This system distinguishes between the nitrogen (protein) requirements of the rumen microbes and the animal. The 1996 NRC model requires a value for protein degradability in the feed matrix. Although the data base needs to be expanded, more protein degradability data have become available since the inception of the 1996 NRC model. A deficiency in the application of the MP system in the 1996 model is the lack of an equation to model microbial efficiency for cattle consuming low-quality diets. 
The objective of this paper was to evaluate and discuss the application of the 1996 NRC model to range cattle nutrition, with special consideration for inputs, energy intake predictions, nutrient status predictions, and the MP system.

\section{Review and Discussion}

Energy Intake. The use of body condition score (BCS) is an appropriate tool to gauge cow energy status as it relates to reproductive function (Richards et al., 1986). The NRC model calculates cow BCS change (days to gain or lose a BCS) from animal and dietary inputs. Predictions of changes in BCS are particularly valuable to model users in building or evaluating nutritional programs for appropriate cow BCS management, designing experiments, and evaluation of published literature.

The BCS prediction feature of the model was used to evaluate published literature with the following objectives: 1) to compare outputs from the model to published results and 2) to develop recommendations for model application to cow-calf production. Studies with grazing cows were identified that met the following criteria: 1) cow BCS or BCS change was reported; 2) energy and protein content of grazed forage were or could be defined; and 3) cattle production traits were or could be defined, including BW, age, breed type, days in lactation, and days pregnant. Studies used in the analysis (Adams et al., 1989, 1993; Hollingsworth-Jenkins et al., 1996; Lamb et al., 1997; Villalobos et al., 1997; Lardy et al., 1999; Ciminski et al., 2002; Jordan et al., 2002) were conducted in Nebraska or Montana and included data generated across various forage maturities, cow biological types, stages of gestation, and environmental conditions. When inadequate data were available to describe cattle diets, models were used to more precisely describe diets (Adams and Short, 1988; Lardy et al., 2004). Forage intake by grazing livestock was predicted using the NRC Model

\begin{tabular}{|c|c|c|c|}
\hline Item & Observed & $\mathrm{TDN}=\mathrm{DE}^{\mathrm{b}}$ & TDN = IVOMD \\
\hline Mean $B C S$ change & -0.209 & -0.114 & 0.322 \\
\hline $\begin{array}{l}P \text { value } \\
\text { Minimum }\end{array}$ & - & 0.44 & 0.001 \\
\hline $\begin{array}{l}\text { BCS change } \\
\text { Maximum }\end{array}$ & -1.3 & -1.2 & -0.41 \\
\hline BCS change & 0.63 & 0.80 & 1.2 \\
\hline & - & 0.73 & 0.74 \\
\hline
\end{tabular}

${ }^{a}$ Adams et al. (1989); Adams et al. (1993); Hollingsworth-Jenkins et al. (1996); Lamb et al. (1997); Villalobos et al. (1997); Lardy et al. (1999); Ciminski et al. (2002); Jordan et al. (2002).

${ }^{\mathrm{b}}$ IVOMD converted to DE for use as TDN in the model using equation of Rittenhouse et al. (1971): DE $=(1.07 *$ IVOMD $)-8.13$.

${ }^{\circ}$ Observed to predicted.

(1996). Predictions of BCS change from the NRC model were compared to published values with dietary TDN entered into the feed matrix as either in vitro OM disappearance (IVOMD) equal to TDN or with IVOMD converted to $\mathrm{DE}[\mathrm{DE}=(1.07 \times \mathrm{IVOMD})-$ 8.13 (Rittenhouse et al., 1971)], assuming DE equal to TDN. Predicted BCS change for each evaluated experimental period was calculated by dividing the NRC model reported days to change a BCS into the number of days in the experimental period. The relationship between predicted and reported BCS change was analyzed by ANOVA in PROC GLM of SAS (SAS Inst. Inc., Cary, NC). Adjustments for activity were not used (Lardy et al., 2004), and environmental conditions were as follows: previous temperature, $-4.4^{\circ} \mathrm{C}$; current temperature, $-1.1^{\circ} \mathrm{C}$; and wind, $8 \mathrm{~km} / \mathrm{h}$. Actual breed types were entered into the model, and the model predicted the magnitude and duration of lactation.

When the calculated DE (Rittenhouse et al., 1971) value was entered into the model as TDN, observed BCS change was not different $(P=0.44)$ than predicted by the NRC model (Table 1 ). The minimum and maximum
BCS changes were similar for predicted and observed values, and the correlation between predicted and observed BCS change was 0.73 . These results indicate the model reliably predicted energy intake, nutrient status, and BCS change. When IVOMD was used as TDN, the model overestimated $(P=0.001)$ BCS change (overestimate of energy intake) compared to reported values (Table 1).

Scientists often report chemical content and digestibility estimates of masticate samples on an OM basis because such samples may contain significant ash contamination (Wallace et al., 1972). Chemical content of forages can be converted back to a DM basis using values reported in the literature for ash content or by measuring the ash content of clipped samples. The IVOMD cannot be converted to a DM basis because the digestibility of ash is not known. Our observations show that using IVOMD to represent TDN consistently yields a greater TDN value than using DE from the Rittenhouse et al. (1971) equation. In vivo digestibility values should be used when available. It is important to note that the conversion of IVOMD to DE is critical in 
bringing the model predictions of BCS change in line with reported values. The model is very sensitive to the value entered for TDN, as this value is used in both the calculations to predict DMI and NE content of the feed. Consequently, an accurate estimation of dietary TDN is critical.

All of the studies evaluated in the above analysis were with grazing cattle, but the grazing activity feature in the model was not used. The 1996 NRC model increases energy requirements as much as $50 \%$ for grazing activity. Adjustments for activity in the experiments evaluated would have resulted in greater energy requirements and would have either reduced the predicted number of days to lose a BCS or increased the predicted number of days to gain a BCS.

The model adjusts energy requirements for environmental temperature in 2 ways: 1) acclimatization (based on previous temperature) and 2) cold or heat stress (based on current temperature). The model is sensitive to wind speed when the current temperature is less than the Lower Critical Temperature. The Lower Critical Temperature is calculated in the model based on heat increment and the insulation factor. The model is also sensitive to hide, hair, mud, and BCS entries because these factors are used in calculating the insulation factor and cold stress. Wind speed and temperature effects on the animal based on reported weather observations would be expected to be less than predicted because cattle adjust to temperature by changing their orientation to wind (i.e., wind breaks and herd positioning) and shade (NRC, 1996).

The combination of inputs used for energy intake, wind speed, hair, hide, mud, and current temperature did not result in cold stress in any of the experiments modeled (Table 1), so these factors did not adjust basal maintenance requirements. In the model results reported here, only the previous temperature entry adjusted $\mathrm{NE}_{\mathrm{m}}$ requirements for environmental conditions, which increased $\mathrm{NE}_{\mathrm{m}}$ requirements by $14 \%$ for acclimatiza- tion. Across the summer and winter studies we modeled, this adjustment appeared appropriate. Surely cattle in the winter-grazing experiments experienced cold stress on some days, but we considered these effects to be nominal. The model uses both mud and current temperature to adjust DMI. With the temperature entered for the modeling described above, there was a $5 \%$ increase in predicted DMI due to current temperature. It is recommended that long-term monthly averages be used when ambient temperature and wind speed are inputs into the model. For environmental conditions normally encountered in the Northern Great Plains, using normal hide thickness, clean and dry hair, and a hair depth of 0.5 inches in the winter and 0.2 inches in the summer is recommended.

There are situations where weather stress (CSIRO, 1990) and grazing activity (NRC, 1996) increase the energy requirements of cattle. The $14 \%$ increase in maintenance requirements used in the analysis reported here appropriately accounted for any increase in maintenance requirements.

The studies chosen to evaluate model predictions of BCS change had complete descriptions of animal BW, age, breed type, and physiological state. These are critical inputs for the model to work correctly. The model requires inputs of shrunk BW (usually $0.96 \times$ full weight), both current and mature. Weights entered into the model need not include the BW of the conceptus, as the model calculates conceptus BW based on stage of gestation. Cow BW taken in the first trimester of pregnancy likely reflect true cow BW. The age entry is also important, as cows less than 60 mo old are assumed to have a requirement for growth. The entry for age also affects milk production estimates. The milk production entry into the model is for a mature cow (greater than 47 mo old), regardless of the age entered. Cattle that are up to 36 mo old are assumed to have $74 \%$ of the peak milk production of a mature cow, so in generating the milk production curve the model multiplies the entry by 0.74 to obtain the peak milk production estimate. Cows that are between 36 and 47 mo old are assumed to have $88 \%$ of the peak milk production of a mature cow. The entry for age does not affect intake predictions, but the entry in the "Animal Type" category does. Replacement heifers have different requirements and intake predictions than cows.

A significant advancement to grazing cattle nutrition in the 1996 NRC model is in the ability to generate requirements and predict intake across a continuum of animal weights and physiological states. The $\mathrm{NE}_{\mathrm{m}}$ requirements of a 550-kg cow across days since calving from the 1984 NRC tables and from the 1996 NRC model is given in Figure 1. Use of the 1996 model allows requirements to be calculated at any given point across an animal's production cycle. This is possible by generation of conceptus growth curves and lactation curves.

Working with the model in our laboratories and in validating data for this review, it was observed that short modeling periods were essential in late gestation and early lactation when requirements change rapidly. For example, Figure 1 shows the requirements of a pregnant cow change markedly as she advances from the ninth through the 12th mo post-calving. The use of an average number to represent stage of gestation or days in lactation during the last trimester of gestation or early lactation is imprecise because requirements change greatly during these time periods. Modeling in 30-d intervals or less was preferable to longer periods in late gestation and early lactation because it more closely approximates day-today changes in requirements.

Accurate inputs for breed types are important as well. In this validation modeling, actual breed types were used and the model predicted the requirements for conceptus growth and lactation. Based on results in Table 1, it was concluded that the model appropriately predicted these require- 


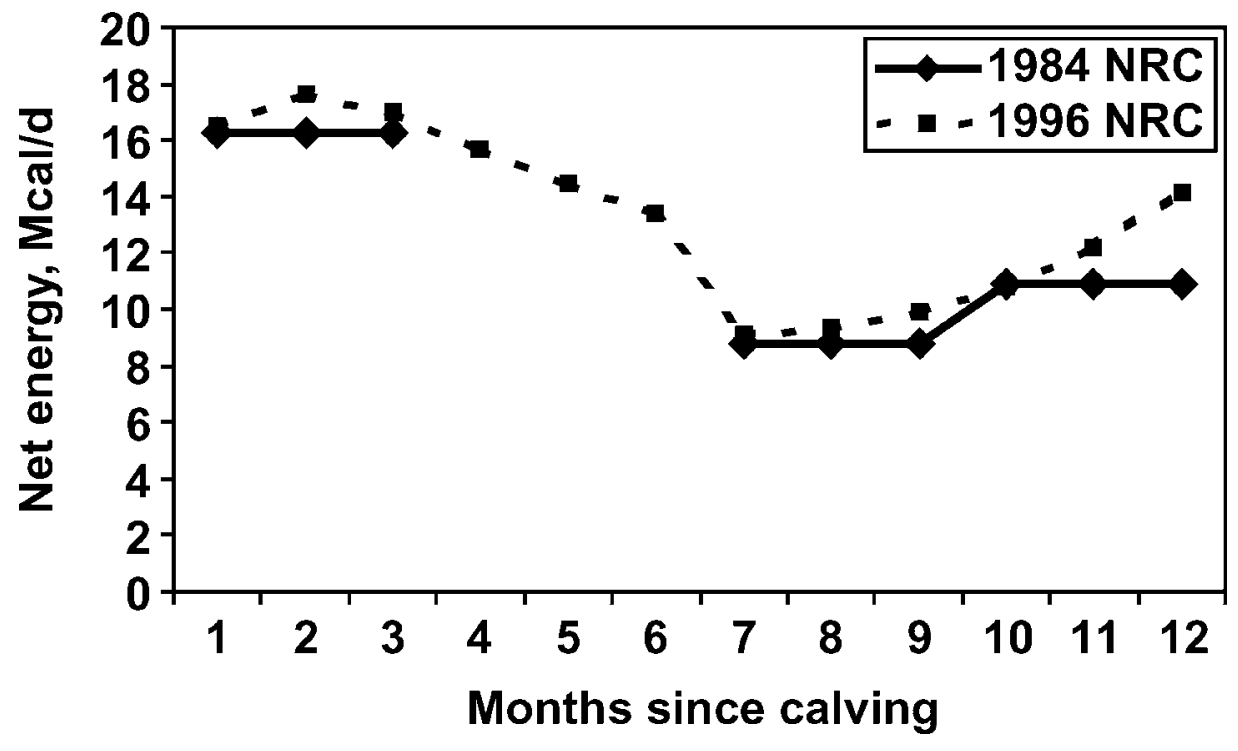

Figure 1. Monthly net energy requirements of a $550 \mathrm{~kg}$ cow with a 10-kg peak milk production reported by NRC (1984) or NRC (1996).

ments for the experiments analyzed. The NRC (1996) predicts BW, peak milk productions, and maintenance multipliers for various breeds. Data used to build the NRC model indicated some breeds have different maintenance requirements than others (i.e., Simmental 20\% greater, Brahman $10 \%$ less, etc.). Breed inputs should be chosen carefully. Users should be aware that variation in milk production exists within breeds. If milk production is expected to vary from predictions in the model, peak milk production can be predicted from mature cow BW and 7-mo weaning BW of calves (NRC, 1996).

It is also important to consider rapidly changing nutrient content of grazed forage. The monthly protein content of the Nebraska Sandhills range is presented in Figure 2 (Lardy et al., 2004). Nutrient quality changes rapidly during plant growth and senescence. When forage quality is changing, it is important to model short time intervals to ensure output accuracy. As with nutrient requirements of the animal, the shorter the time period to be modeled, the closer a given nutrient composition will represent day-to-day changes in forage nutrients. ply of DIP is essential for sufficient utilization of ingested feedstuffs (Köster et al., 1996). Rumen microorganisms flow from the rumen attached with feed and in fluid. The NRC (1996) reported that microorganisms are $80 \%$ true protein, which is $80 \%$ digestible. Rumen microorganisms can supply 50 to $100 \%$ of the protein required by the animal (NRC, 1996). A portion of ingested protein is undegradable intake protein (UIP) that escapes rumen degradation and supplies amino acids to the animal. The NRC (1996) assumes UIP is 80\% digestible. Metabolizable protein, or absorbed protein, is comprised of microbial CP (MCP) and UIP. The equation to predict MP supply is as follows:

Eq. 1. $\mathrm{MP}(\mathrm{g} / \mathrm{d})=[\mathrm{MCP}(\mathrm{g} / \mathrm{d}) \times 0.80 \times$ $0.80]+[\mathrm{UIP}(\mathrm{g} / \mathrm{d}) \times 0.80]$

A cornerstone to application of the MP system is an accurate estimate of MCP production. Microbial CP production is important to determine both MP supply and DIP requirements. After reviewing the literature, The Subcommittee on Beef Cattle Nutrition chose TDN intake as the determinant of MCP production (NRC, 1996). Microbial CP production is predicted by the less of the following 2 equations:

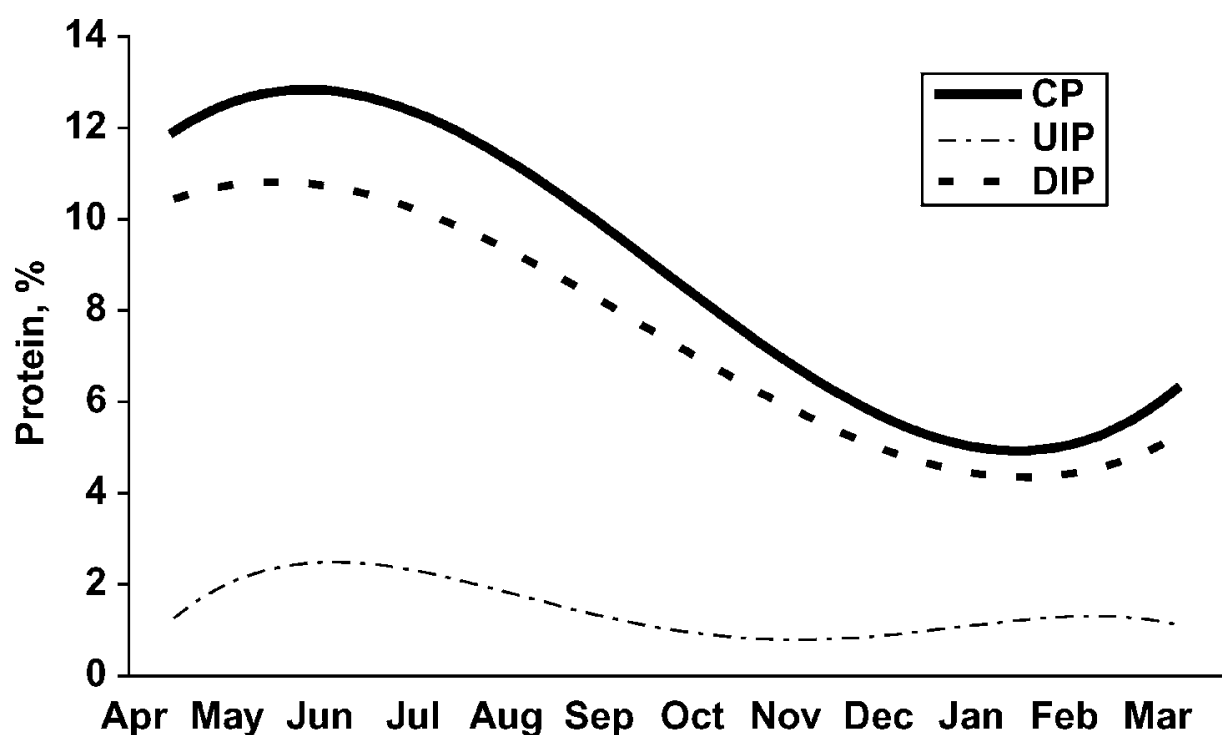

Figure 2. The CP, degradable intake protein (DIP) and undegradable intake protein (UIP) content of Nebraska Sandhills range (Lardy et al., 2004). 
Eq. 2. $\mathrm{MCP}(\mathrm{g} / \mathrm{d})=\mathrm{TDN}$ intake $(\mathrm{kg} / \mathrm{d})$ $\times$ microbial efficiency $(\mathrm{g} / \mathrm{kg})$

Eq. 3. MCP $(\mathrm{g} / \mathrm{d})=$ DIP intake $(\mathrm{g} / \mathrm{d})$

Level 1 of the NRC model assumes DIP deficiencies will be met through supplementation; thus, Eq. 2 is used regardless of DIP balance. The requirements for DIP are likewise determined by Eq. 2 (DIP requirement is assumed to be equivalent to MCP production).

Microbial efficiency is the rate of energy incorporation into MCP. The model assumes microbial efficiency is $130 \mathrm{~g} / \mathrm{kg}$ TDN intake (13\%) unless effective NDF (eNDF) is less than $20 \%$. Dietary eNDF levels less than $20 \%$ occur when concentrate feeds make up a high percentage of the diet, and these situations are associated with decreased ruminal $\mathrm{pH}$. At low rumen $\mathrm{pH}$, rumen microbes expend energy maintaining intracellular $\mathrm{pH}$ and consequently are less efficient in production of MCP. The model reduces efficiency of MCP production by $2.2 \%$ for every $1 \%$ decrease in forage eNDF below $20 \%$. Research data indicates microbial efficiency is also reduced with lesser quality forages as a slower rate of passage results in slower microbial turnover and elevated microbial maintenance requirements. The Subcommittee on Beef Cattle Nutrition (NRC, 1996) reviewed 5 studies (Stokes et al., 1988; Krysl et al., 1989; Hannah et al., 1991; Lintzenick et al., 1993; Villalobos, 1993) to evaluate microbial efficiency at various diet digestibilities. Across experiments, diet OM (DOM) disappearance ranged from 49.8 to $64.7 \%$. Microbial CP production ranged from 5.0 to $11.4 \%$ of DOM, with an average of $7.82 \%$. The authors were not able to develop a relationship between diet digestibility and MCP production from these studies. Subsequent work with spring-calving cows grazing winter range (Hollingsworth-Jenkins et al., 1996) reported a DIP requirement (assumed MCP production) of $6.65 \%$ of DOM (diet $\mathrm{DOM}=55.8 \%$ ). Work with summercalving cows in late winter and spring (Lardy et al., 1997) showed a DIP requirement of $9.45 \%$ of DOM (diet DOM $=53.5 \%$ ). It is apparent that microbial efficiency is reduced with lower quality diets; however the NRC (1996) did not model the relationship at the time of publication. The 1996 NRC model requires a manual adjustment in microbial efficiency for lesser quality diets.

Recent work has evaluated urinary allantoin, a byproduct of purine metabolism, as marker for MCP production (Lamothe et al., 2002, 2003). Urine was collected from cows grazing range in the Nebraska Sandhills for 5 consecutive $d$ following adaptation in each of the months of May, June, July, August, September, and December. Creatinine was used as a marker to determine urine output (creatinine output assumed at 0.14 $\mathrm{mmol} / \mathrm{kg} \mathrm{BW}$ ). The ratio of allantoin to creatinine was used to estimate MCP production. Diets were collected using esophageal-fistulated cows during each month, and samples were analyzed for IVOMD. Intake was predicted by the NRC model. Microbial efficiency was expressed as MCP production across DE (IVOMD converted to $\mathrm{DE}$ by equations of Rittenhouse et al., 1971). The relationship between DE and microbial efficiency calculated from the urinary allantoin data $(P=0.05)$ is shown in Figure 3. Variation in the data $\left(\mathrm{R}^{2}=0.32\right)$ is not surprising given the assumptions and calculations used to calculate MCP production (intake, diet digestibility, creatinine as a measure of urine output, and allantoin as a measure of $\mathrm{MCP})$. Of importance, however, is that a relationship was developed (in a production setting) between diet digestibility and microbial efficiency.

Based on data showing reduced microbial efficiency with lesser quality diets (NRC, 1996) and urinary allantoin data showing a relationship between diet digestibility and microbial efficiency (Lamothe et al., 2002, 2003), we propose the use of an idealistic equation (Figure 4) for diets less than $65 \%$ TDN, as first described by Klopfenstein et al. (2000):
Eq. 4: Microbial efficiency $(\mathrm{g} / 100 \mathrm{~g}$

$\mathrm{TDN}$ intake $)=2.62+(1.78 \times \% \mathrm{TDN})$ $-\left[\left(9.60 \times 10^{-2}\right) \times \% \mathrm{TDN}^{2}\right]+[(1.78 \times$ $\left.\left.10^{-3}\right) \times \% \mathrm{TDN}^{3}\right]-$ $\left[\left(1.05 \times 10^{-5}\right) \times \% \mathrm{TDN}^{4}\right]$.

The use of this equation allows application of the MP system to situations where diet TDN is less than $65 \%$, and gives scientists a model useful in design of validation experiments.

The estimate of microbial efficiency used in the model is important in determining both MP supply and the requirement for DIP. For spring calving cows grazing winter range in the Nebraska Sandhills, the model is sensitive to estimates of microbial efficiency (Table 2; Lardy et al., 2004). For example, when a microbial efficiency of $13 \%$ is used, the model predicted that cows are over $150 \mathrm{~g} / \mathrm{d}$ deficient in DIP and positive in MP. If microbial efficiency is assumed to be $8 \%$ of TDN intake, DIP balance was $100 \mathrm{~g} / \mathrm{d}$ positive, whereas MP was over $100 \mathrm{~g} / \mathrm{d}$ negative. A supplementation regimen would be very different depending on the microbial efficiency value used. The relationship between MP supply and DIP requirement makes an accurate estimate of microbial efficiency important to effective application of the MP system. It is also important to remember that Level 1 of the NRC model does not adjust MP supply or digestibility of feedstuffs for a DIP deficiency, which are 2 things known to be impacted when DIP is inadequate. Model users can adjust MP supply for DIP deficiency using the assumption that $1 \mathrm{~g}$ DIP $=0.64 \mathrm{~g}$ of MP. Estimates of reductions in digestibility and intake in DIP deficient situations are more difficult to assess and likely depend on the degree of DIP deficiency, characteristics of the diet in question, and the supplementation program. Köster et al. (1996) reported that DIP supplementation for cattle consum- 


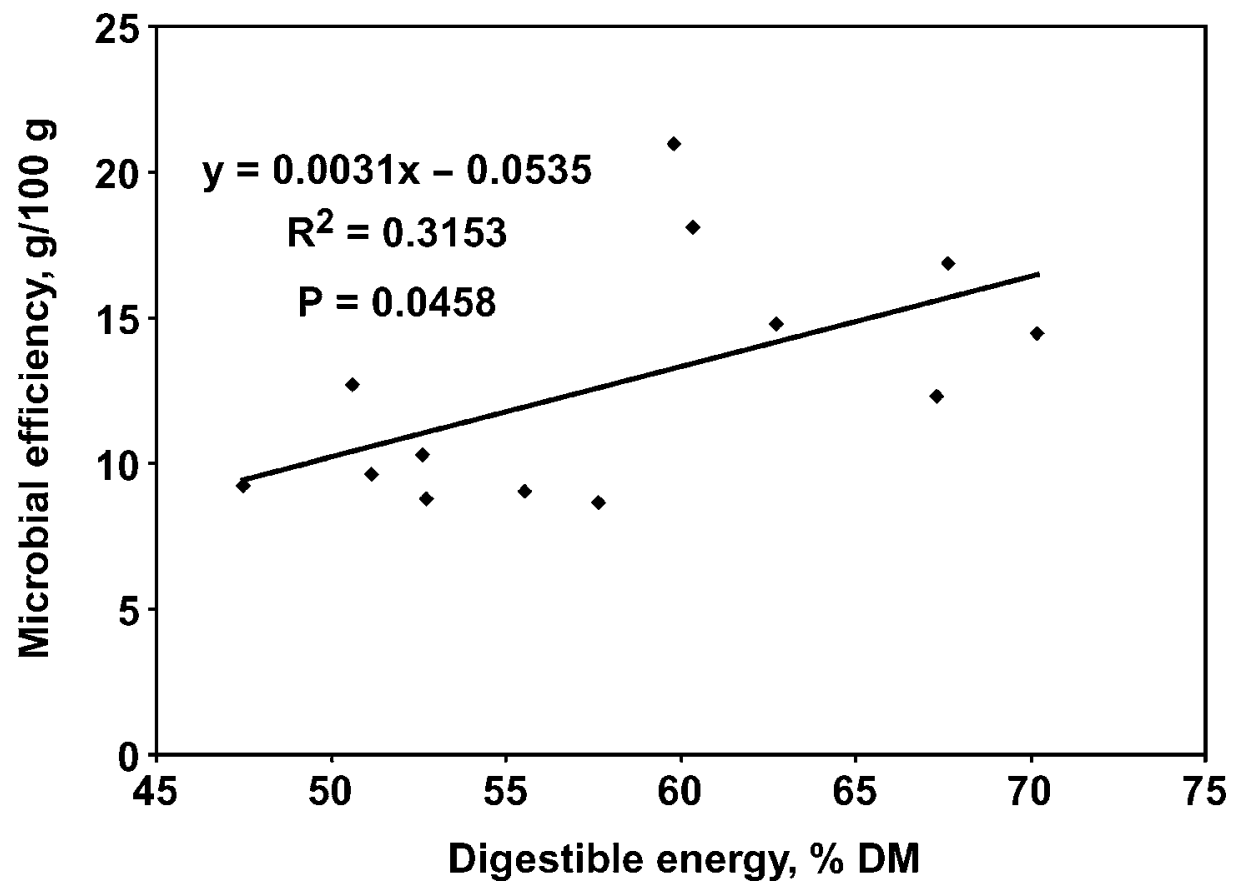

Figure 3. Relationship between diet digestibility and microbial efficiency ( $\mathrm{g} / 100 \mathrm{~g}$ of DE intake) as determined by urinary allantoin (Lamothe et al., 2002, 2003).

ing low-protein forage increased digestibility and forage intake, whereas other reports have shown variable responses to protein supplementation (Rittenhouse et al., 1970; Kartchner, 1981). Although difficult to assess, differences be- tween studies on the effects of supplemental protein on forage digestibility and intake may be due to differences in DIP deficiency and DIP supply from supplements.

It is important to note that Level 1 of the NRC model assumes no

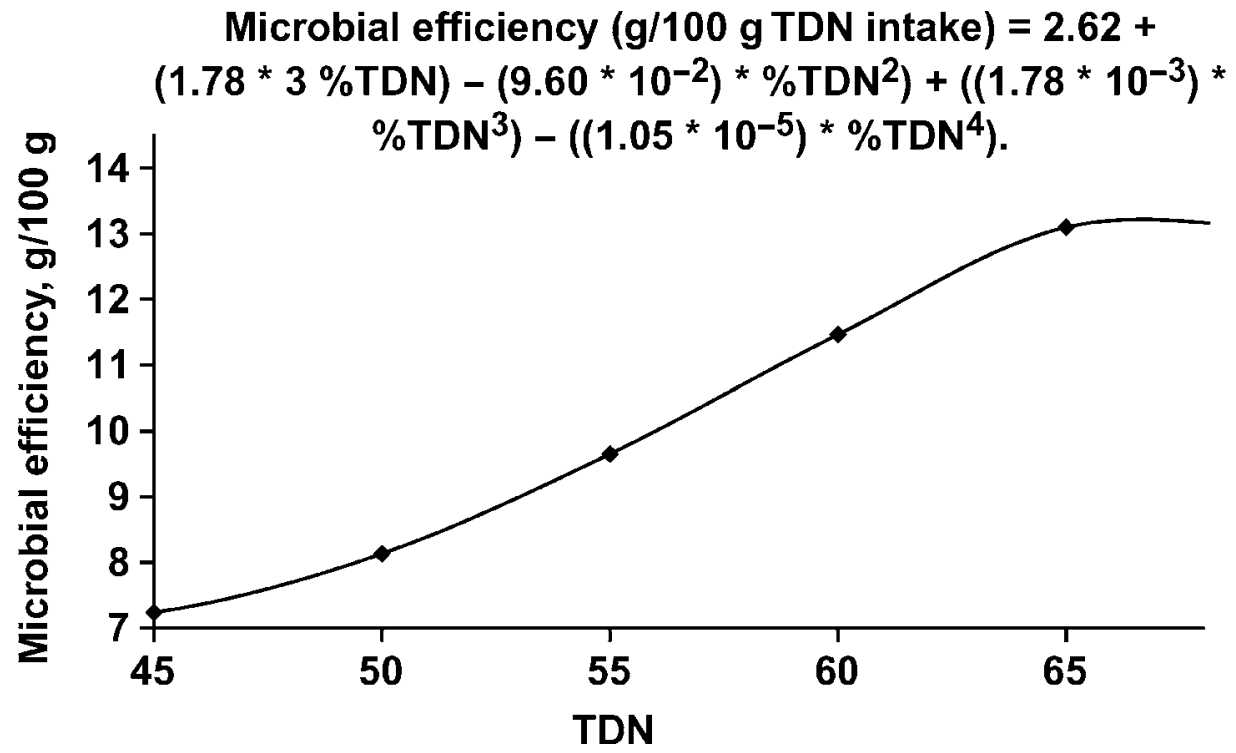

Figure 4. An idealistic equation describing the relationship between diet TDN and microbial efficiency (g/100g TDN intake) for diets less than 65\% TDN (Klopfenstein et al., 2000).

net $\mathrm{N}$ recycling when DIP intake $=$ MCP production. When ruminal N is at balance, recycling of $\mathrm{N}$ via saliva, diffusion, or both is assumed to be equivalent to the amount of ammonia-nitrogen leaving the rumen in digesta flow. In the current version of the model, there are no assumptions regarding situations when ruminal $\mathrm{N}$ is not at balance. In addition, recycling of excess MP (MP above the animal's requirement) is not modeled, but likely occurs on a variety of diets. Little research exists which has attempted to quantify these processes.

As previously mentioned, it is imperative that an accurate estimate of TDN concentration be used in the model. Dietary TDN has multiplicative effects on MP, as it affects both TDN intake (through TDN concentration and DMI) and microbial efficiency. The influence of dietary TDN on microbial efficiency (using the equation of Klopfenstein et al., 2000), predicted DMI, DIP balance, and MP balance for a cow that is $225 \mathrm{~d}$ in gestation is given in Table 3. When dietary TDN is $47 \%$, DIP balance is $48 \mathrm{~g} / \mathrm{d}$ and MP balance is $-177 \mathrm{~g} / \mathrm{d}$. This is contradictory to reports that DIP is the first-limiting nutrient for springcalving cows grazing native winter range (Hollingsworth-Jenkins et al., 1996). Results in Table 3 show that MP may be limiting before DIP when energy intake is low. When dietary TDN is $52 \%$, DIP and MP are -55 and $-73 \mathrm{~g} / \mathrm{d}$, respectively. Modest changes in dietary TDN concentration result in different conclusions based on output from the 1996 NRC model. It is also important to realize dietary fat and UIP contribute to the TDN value of a feedstuff but do not provide fermentable substrate for MCP production. Therefore, using book values for the TDN concentration of feedstuffs high in fat or UIP may result in overestimation of MP supply and DIP requirements.

The 1996 NRC model was used to describe diets in the work of Hol- 
TABLE 2. Effect of microbial efficiency on degradable and metabolizable protein requirement, supply, and balance for a gestating spring calving cow consuming dormant winter range. ${ }^{a}$

\begin{tabular}{lrrrrrr} 
& \multicolumn{6}{c}{ Microbial Efficiency, \% } \\
\cline { 2 - 7 } Item $^{\text {b }}$ & $\mathbf{8 \%}$ & $\mathbf{9 \%}$ & $\mathbf{1 0 \%}$ & $\mathbf{1 1 \%}$ & $\mathbf{1 2 \%}$ & $\mathbf{1 3 \%}$ \\
\hline DIP supply, g/d & 518 & 518 & 518 & 518 & 518 & 518 \\
DIP requirement, g/d & 422 & 475 & 528 & 581 & 633 & 686 \\
DIP balance, g/d & 96 & 43 & -10 & -62 & -115 & -168 \\
MP supply, g/d & 355 & 388 & 422 & 456 & 490 & 524 \\
MP requirement, g/d & 470 & 470 & 470 & 470 & 470 & 470 \\
MP balance, g/d & -116 & -82 & -48 & -14 & 20 & 54
\end{tabular}

aLardy et al. (2004).

${ }^{\mathrm{b}} \mathrm{DIP}=$ degradable intake protein; $\mathrm{MP}=$ metabolizable protein.
lingsworth-Jenkins et al. (1996) in order to evaluate nutrient balances in relation to treatments and to compare predicted and actual performance data (Table 4). In this experiment, graded levels of DIP were fed to March-calving cows from November to February. Cattle BW and BCS responded quadratically and cubically, respectively, to increased DIP. The authors concluded that gestating cows grazing native Nebraska Sandhills range required between 62 and $140 \mathrm{~g}$ of DIP per day (dietary TDN was 54\%). The NRC model predicted DIP was slightly deficient $(-15 \mathrm{~g} / \mathrm{d})$ when $140 \mathrm{~g}$ DIP was supplemented, and DIP was in excess when DIP supplementation exceeded $140 \mathrm{~g} / \mathrm{d}$ (Table 4). Since performance was not further improved when supplemental DIP was in excess of $140 \mathrm{~g} / \mathrm{d}$, these predicted DIP balances were consistent with the measured responses in weight and BCS change. However, the model predicted BCS change to be more positive than that observed in the study. A negative MP balance in all treatments may have resulted in less than predicted performance. It is not clear if the defi-
TABLE 3. Predictions of dry matter intake, degradable intake protein (DIP) balance, and metabolizable protein (MP) balance of cows grazing winter range when forage TDN ranges from 47 to $52 \%$ of DM. ${ }^{a b}$

\begin{tabular}{lcccc} 
Item & $\begin{array}{c}\text { Microbial Efficiency, } \\
\mathbf{g} / \mathbf{1 0 0} \mathbf{~} \text { TDN }^{\mathbf{c}}\end{array}$ & $\mathbf{D M I ,} \mathbf{~} \mathbf{g} / \mathbf{d}$ & DIP balance, $\mathbf{g} / \mathbf{d}$ & MP balance, $\mathbf{g} / \mathbf{d}$ \\
\hline 47 & 7.5 & 9.9 & 48 & -177 \\
48 & 7.7 & 10.3 & 33 & -153 \\
49 & 7.9 & 10.7 & 15 & -127 \\
50 & 8.1 & 11.0 & -4 & -101 \\
51 & 8.4 & 10.9 & -29 & -91 \\
52 & 8.7 & 10.9 & -55 & -73 \\
\hline
\end{tabular}

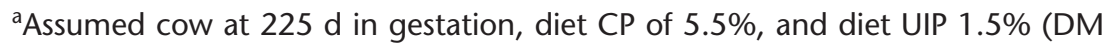
basis).

${ }^{b}$ Predictions derived from the NRC (1996).

'Microbial efficiency calculated using the equation of Klopfenstein et al. (2000). ciency in MP confounded results of the study. Environmental effects may have also caused observed BCS changes to be less than predicted in this particular study. The NRC model output shown in Table 4 was generated with no adjustment for environmental conditions, but the experiment was conducted in the fall and winter when cold temperatures may have elevated energy requirements.

Using the NRC model, 53 individual diet calculations were made with experimental diets from 10 published studies (Adams et al., 1989, 1993; Hollingsworth-Jenkins et al., 1996; Lamb et al., 1997; Lardy et al., 1997; Villalobos et al., 1997; Lardy et al., 1999; Ciminski et al., 2002; Jordan et al., 2002; Patterson et al., 2003a) to evaluate MP balance. Of the 53 diets evaluated, 47 had negative MP balances. The expected nutrient balances of grazing cows consuming winter range at various stages of late pregnancy are shown in Table 5 (as modeled in the NRC, 1996). The model predicted MP and $\mathrm{NE}_{\mathrm{m}}$ to both be negative during late gestation. Interestingly, at $260 \mathrm{~d}$ of gestation, supplementation with $1.0 \mathrm{~kg}$ of soybean meal would supply adequate DIP, $\mathrm{MP}$, and $\mathrm{NE}_{\mathrm{m}}$. Some UIP in supplements for gestating cows appears to be needed, and feedstuffs such as soybean and cottonseed meal contain significant amounts of UIP compared to supplements containing non-protein $\mathrm{N}$. The fact that some UIP is necessary for pregnant cows grazing winter range may partially explain why research using non-protein $\mathrm{N}$ as the primary source of DIP resulted in lesser levels of performance compared to natural protein supplements for cattle consuming poor quality forage (Rush and Totusek, 1975). The NRC model is a useful tool for identifying nutrient deficiencies and for designing appropriate supplementation regimens. Use of the MP system (NRC, 1996) in protein supplementation research would avoid 
TABLE 4. Predicted nutrient balances and body condition score (BCS) change compared to observed change for grazing cows supplemented with graded levels of degradable intake protein (DIP). ${ }^{\text {ab }}$

Level of daily DIP supplementation (g)

\begin{tabular}{lcccc}
\cline { 2 - 5 } Item & $\mathbf{6 4}$ & $\mathbf{1 4 0}$ & $\mathbf{2 1 8}$ & $\mathbf{3 0 0}$ \\
\hline Predicted intake, kg/d & 10.6 & 10.6 & 10.6 & 10.6 \\
DIP balance g/d & -92 & -15 & 60 & 144 \\
MP balance, g/d & -112 & -67 & -61 & -66 \\
$\mathrm{NE}_{\mathrm{m}}$ balance, Mcal/d & 1.63 & 1.63 & 1.63 & 1.63 \\
Predicted BCS change & 0.8 & 0.8 & 0.8 & 0.8 \\
Actual BCS changec & -0.2 & 0.0 & -0.4 & -0.3
\end{tabular}

${ }^{a}$ Adapted from Hollingsworth-Jenkins et al. (1996). Dietary $C P=4.85 \%$; UIP $=$ $1.0 \% ;$ TDN $=54 \%$ (DM basis); microbial efficiency assumed at $9.3 \%$ (Klopfenstein et al., 2000). Cows were supplemented November through February and average $220 \mathrm{~d}$ in gestation.

b Predictions derived from the NRC (1996).

${ }^{\mathrm{C}} \mathrm{MP}=$ metabolizable protein.

${ }^{\mathrm{d}}$ Cubic effect, $P<0.01$.
MP deficiencies that confound results.

Recent reports evaluated the MP system in developing supplements for young cows. Patterson et al. (2003b) supplemented March-calving heifers during gestation to meet either $\mathrm{CP}$ or MP requirements. The supplement designed to meet $\mathrm{CP}$ requirements was based on cottonseed and soybean meal and supplied $57 \mathrm{~g}$ of UIP/d from October to February. The supple- ment designed to meet MP requirements was based on sunflower and feather meal and supplied from 87 $\mathrm{g}$ UIP/d in October to $209 \mathrm{~g} \mathrm{UIP} / \mathrm{d}$ in February. Heifers grazed native Sandhills range and received approximately $2.0 \mathrm{~kg}$ of hay/d in January and February. One group of heifers receiving the MP-designed supplement did not receive hay. The nutrient balances of the heifers at 2 different stages of gestation are presented in Table 6 . Cows that
TABLE 5. Predicted degradable intake protein (DIP), metabolizable protein (MP), and $\mathrm{NE}_{\mathrm{m}}$ balances of cows grazing native winter range at various stages of pregnancy. ${ }^{a b}$

\begin{tabular}{cccc} 
Item & DIP balance, $\mathbf{g} / \mathbf{d}$ & MP balance, $\mathbf{g} / \mathbf{d}$ & $\mathbf{N E}_{\mathbf{m}}$ balance, Mcal/d \\
\hline 200 & -4 & -67 & 0.31 \\
220 & -4 & -93 & -0.27 \\
240 & -4 & -128 & -1.04 \\
260 & -4 & -175 & -2.02 \\
280 & -4 & -239 & -3.24
\end{tabular}

${ }^{\mathrm{a}}$ Assumptions: $\mathrm{DM}$ intake $=11.0 \mathrm{~kg}$; dietary CP $=5.5 \%$; UIP $=1.5 \% ; \mathrm{TDN}=$ $50 \%$; microbial efficiency $=8.1 \%$ (DM basis); $544 \mathrm{~kg}$ Angus cow; $36 \mathrm{~kg}$ birth weight.

b Predictions derived from the NRC (1996). were supplemented to meet $\mathrm{CP}$ requirements had a negative MP balance, especially in February when the deficiency reached $125 \mathrm{~g} / \mathrm{d}$. Heifers supplemented to meet MP requirements only had an $11-\mathrm{g}$ MP deficiency in February if fed hay; however, those heifers which did not receive hay had greater levels of $\mathrm{NE}_{\mathrm{m}}$ and MP deficiency. Supplementation did not make up for deficiencies in energy intake in the group not receiving hay, and those heifers lost more BW and BCS than heifers receiving hay. Although supplementing to meet MP requirements alleviated MP deficiencies, there were not large differences in $\mathrm{BW}$ or BCS change between CP and MP supplemented heifers.

A simultaneous study on a commercial ranch (Patterson et al., 2003a) used 2,120 gestating heifers over $2 \mathrm{yr}$ and 2 locations to evaluate effects of supplement protocols designed to meet either $\mathrm{CP}$ or MP requirements (supplement regimens as described above for Patterson et al., 2003b). Heifers calved in March and April, and subsequent 2-yr-old pregnancy rates were measured each year. Heifers grazed range and were fed hay from late December until February. There were no differences between treatments in heifer BW or BCS change from September to February of either year. However, cattle supplemented to meet MP requirements had a greater subsequent pregnancy rate than those supplemented to meet $\mathrm{CP}$ requirements (91 and 86\% for MP-supplemented and CP-supplemented, respectively). Evaluation of diets with the 1996 NRC model revealed that heifers supplemented to meet CP requirements were markedly deficient in MP in February (immediately prior to calving), whereas those supplemented to meet MP requirements had positive MP balances. In this study, supplemental UIP to meet MP requirements improved reproduction in young cows.

Due to the high protein requirements of cows during lactation, 
TABLE 6. Predicted $\mathrm{NE}_{\mathrm{m}}$, metabolizable protein (MP), and degradable intake protein (DIP) balances of March calving heifers supplemented to meet MP requirements and fed hay, CP requirements and fed hay, or MP requirements and not fed hay at 2 dates during gestation. ${ }^{\text {abc }}$

\begin{tabular}{lccccccc} 
& \multicolumn{3}{c}{ December } & & \multicolumn{3}{c}{ February } \\
\cline { 2 - 3 } Item & $\mathbf{C P}+$ Hay & MP + Hay & MP - Hay & & CP + Hay & MP + Hay & MP - Hay \\
\hline DMI, kg/d & 7.7 & 7.1 & 8.5 & & 8.2 & 8.0 & 6.0 \\
NE $E_{m}$ balance, Mcal/d & -0.9 & -1.2 & 0.3 & & -3.3 & -3.0 & -5.1 \\
DIP balance, g/d & 108 & 68 & 66 & & 122 & 132 & 101 \\
MP balance, g/d & -26 & 13 & 61 & -125 & -11 & -82
\end{tabular}

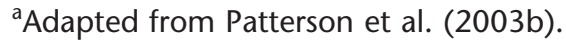

bPredictions derived from the NRC (1996).

${ }^{\mathrm{C}} \mathrm{CP}+$ Hay $=$ grazing heifers supplemented to meet $\mathrm{CP}$ requirements and fed hay at $2.2 \mathrm{~kg} / \mathrm{d}$ in February; MP + Hay = grazing heifers supplemented to meet MP requirements and fed hay at $2.2 \mathrm{~kg} / \mathrm{d}$ hay in February; MP - Hay: grazing heifers supplemented to meet MP requirements and not fed hay. No heifers received hay in December.

many diets are deficient in MP for young cows during the postpartum period. Patterson et al. (2003b) fed lactating 2-yr-olds medium quality, meadow grass hay $(9.5 \% \mathrm{CP})$ with supplements fed to either meet DIP or MP requirements. Supplemental UIP to meet MP requirements decreased cow BW loss during the 64 $\mathrm{d}$ of the study, but there was no improvement in postpartum interval with UIP supplementation.

Wiley et al. (1991) supplemented both thin and moderate condition 2-yr-old cows during early lactation with either $250 \mathrm{~g}$ DIP/d or $250 \mathrm{~g}$ of DIP plus an additional $250 \mathrm{~g}$ of UIP/d. Supplementation with UIP increased postpartum BW change and the percentage of heifers bred in $21 \mathrm{~d}$ (65.5 vs. $43.3 \%$ for DIP + UIP and DIP, respectively). The authors hypothesized that increased insulin levels resulting from supplemental UIP partitioned nutrients towards growth and possibly increased ovarian sensitivity to luteinizing hormone.

Other studies have suggested repartitioning of nutrients associated with UIP supplementation.

Appeddu et al. (1996) supplemented lactating 2-yr-olds with fat, UIP, or UIP plus fat. Supplementation with UIP improved BCS between calving and breeding. Fat supplementation decreased BW gain from calving to breeding and increased milk production; however, addition of UIP to the fat supplemented diet reversed the effects of supplemental fat. Work with mature cows grazing smooth bromegrass supplemented with $230 \mathrm{~g}$ UIP/d showed increased milk production compared to cows not receiving the supplement; however supplementation with $340 \mathrm{~g}$ UIP/d decreased milk production (Blasi et al., 1991).

Recommendations for Using the Model and Developing Research.

Forage and Feed Information. Model users should strive for accurate estimates of feed digestibility and protein content. Diet quality data collected across multiple years are useful in estimating the quality of grazed forage. Forage quality prediction models (Adams and Short, 1988; Lardy et al., 2004) are also a source of diet quality data. If IVOMD is the forage energy estimate used, a conversion of IVOMD to DE (Rittenhouse et al., 1971) may be necessary for use as TDN in the model.

Information is available regarding forage protein degradability, and methods are continually being refined in quest of simple and accurate methods to analyze protein degradability (Klopfenstein et al.,
2001). In recent work at Nebraska and North Dakota, protein degradability of diets collected by cows grazing Northern Great Plains Rangeland was analyzed (HollingsworthJenkins et al., 1996; Lardy, 1997; Johnson et al., 1998; Lardy et al., 1999; Patterson et al., 2000, 2003a,b). These studies, which used various methods of estimating protein degradability and included both cool- and warm- season grasses, revealed the UIP content of dormant forage ranged from 0.5 to $2.0 \%$ of OM. Because UIP content of dormant forages appears to consistently fall within this range, and because the UIP content of dormant forage is a relatively small percentage of intake, the effects of small errors in estimating the degradability of protein in these situations would be nominal. If more specific data are not available, NRC model users should use a value of $1.5 \%$ UIP (DM basis) for dormant native forages. Scientists need to continue to define and simplify methodologies for measuring protein degradability in forages and feedstuffs.

Microbial Efficiency. Unless more specific data are available or until validated equations are developed, model users are encouraged to use the equation proposed by Klopfenstein et al. (2000) to estimate mi- 
crobial efficiency of diets less than 65\% TDN. Development and validation of microbial efficiency models for forages of various digestibility is critically needed. The use of urinary allantoin (Lamothe et al., 2003) and other methodologies may be useful in this process.

Intake. Because of challenges with methods to measure forage intake by grazing cattle in a research setting and the impracticality of measuring intake in production settings, the NRC model is a significant improvement in resources available to researchers and managers for estimating forage intake. The modeling work in this manuscript indicates model intake predictions are satisfactory.

Nutrient Balances. The modeling data presented in this paper indicate that the NRC model accurately predicts cow BCS score change when accurate inputs are available. It is important to note that studies were modeled only where adequate information existed for model inputs. Outputs can only be expected to be as accurate as the input data. Users should remember that model outputs are not perfect estimates when evaluating the degree of predicted deficiencies. For example, a 20-g deficiency in DIP may not be just cause for expensive changes in a supplementation program.

Protein Recycling. The NRC model does not include models for recycling of excess DIP or MP. Development of robust models for protein recycling is needed.

Experimental Design. The CP system does not accurately describe the protein requirements of cattle and is inadequate as a tool in protein supplementation research. When designing experiments, scientists should separate requirements of rumen microbes from that of the host animal. The relationship between energy intake and protein supply and requirements should not be ignored.

\section{Implications}

The NRC model represents a significant advancement to grazing cattle nutrition. We have demonstrated that the model is useful in developing hypotheses, determining nutrient status, identifying limiting nutrients and needed inputs, and in evaluating published literature. The use of the model to predict BCS change of cattle appears to be appropriate if accurate inputs are used in the model. The MP system has application to range cattle nutrition. Scientists and nutritionists can more completely and accurately define protein requirements using the MP system compared to the CP system. Metabolizable protein may be deficient for grazing cows in more situations than previously recognized; therefore, careful attention to balancing MP should be given in production and research settings. What better resources for determining nutrient status of grazing cattle do we have that are more reliable than the 1996 NRC model?

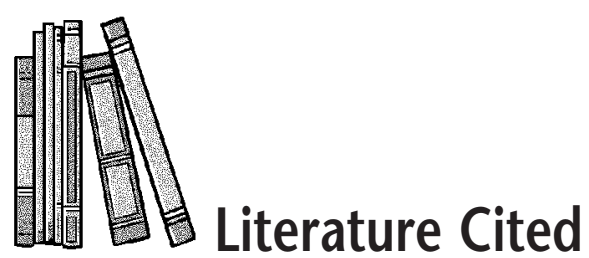

Adams, D. C., and R. E. Short. 1988. The role of animal nutrition on productivity in a range environment. In Achieving Efficient Use of Rangeland Resources. R. S. White, and R. E. Short, ed. p 37. Montana Agric. Exp. Stn., Bozeman.

Adams, D.C., R.B. Staigmiller, and B.W. Knapp. 1989. Beef production from native and seeded Northern Great Plains ranges. J. Range. Manage. 42:243.

Adams, D.C., R.B. Staigmiller, B.W. Knapp, and J. B. Lamb. 1993. Native or seeded rangeland for cows with high or low milk production. J. Range. Manage. 46:474.

Appeddu, L. A., M. K. Petersen, J. S. SerratoCorona, L. F. Gulino, I. Tovar-Luna, G. B. Donar, D. E. Hawkins, J. R. Strickland, E. E. Parker, and S. Cox. 1996. Postpartum reproductive responses of two year old range cows supplemented with protein, fat, or energy. Proc. West. Sec. Am. Soc. Anim. Sci. $47: 2$.

Blasi, D. A., J. K. Ward, T. J. Klopfenstein, and R. A. Britton. 1991. Escape protein for beef cows: III. Performance of lactating beef cows grazing smooth brome or big bluestem. J. Anim. Sci. 69:2294.

Ciminski, L.A. 2002. Fall weaning and winter protein supplementation effects on cow/ calf productivity. M.S. Thesis, Univ. of Nebraska. Lincoln.

CSIRO. 1990. Feeding Standards for Australian Livestock: Ruminants. Commonwealth Scientific and Industrial Research Organization Publications, East Melbourne, Victoria, Australia.

Hannah, S. M., R. C. Cochran. E. S. Vanzant, and L. L. Harmon. 1991. Influence of protein supplementation on site and extent of digestion, forage intake, and nutrient flow characteristics in steers consuming dormant bluestem-range forage. J. Anim. Sci. 69:2624

Hollingsworth-Jenkins, K. J., T. J. Klopfenstein, D.C. Adams, and J.B. Lamb. 1996. Ruminally degradable protein requirement of gestating beef cows grazing native winter range. J. Anim. Sci. 74:1343.

Johnson, J. A., J. S. Caton, W. Poland, D. R. Kirby, and D. V. Dhuyvetter. 1998. Influence of season on dietary composition, intake, and digestion by beef steers grazing mixed-grass prairie in the northern Great Plains. J. Anim. Sci. 76:1682.

Jordan, D. J., T. K. Klopfenstein, and D. C. Adams. 2002. Dried poultry waste for cows grazing low-quality winter forages. J. Anim. Sci. 80:818.

Kartchner, R. J. 1981. Effects of protein and energy supplementation of cows grazing native winter range forage on intake and digestibility. J. Anim. Sci. 51:432.

Klopfenstein, T., R. Cooper, G. Erickson, and H. Block. 2000. Protein (UIP/DIP) supplementation of growing-finishing beef cattle. In Proc. 35th Annu.Pacific Northwest Anim. Nutr.Conf., Spokane, WA.

Klopfenstein, T. J., R. A. Mass, K. W. Creighton, and H. H. Patterson. 2001. Estimating forage protein degradation in the rumen. J. Anim. Sci. 79(E. Suppl.):E208.

Köster H. H., R. C. Cochran, E. C. Titgemeyer, E. S. Vanzant, I. Abdelgadir, and G. StJean. 1996. Effect of increasing degradable intake protein on intake and digestion of low-quality, tallgrass-prairie forage by beef cows. J. Anim. Sci. 74:2473.

Krysl, J. J., M. E. Branine, A. U. Cheema, M. A. Funk, and M. L. Galyean. 1989. Influence of soybean meal and sorghum grain supplementation on intake, digesta kinetics, ruminal fermentation, site and extent of digestion and microbial protein synthesis in beef steers grazing blue gramma rangeland. J. Anim. Sci. 67:3040.

Lamb, J. B., D. C. Adams, T. K. Klopfenstein, W. W. Stroup, and G. P. Lardy. 1997. Range or meadow regrowth and weaning effects on 2-year-old cows. J. Range Manage. 50:16. 
Lamothe, M., T. Klopfenstein, D. Adams, J. Musgrave, and G. Erickson. 2003. Microbial protein production in gestating cows supplemented with different sources of rumen degradable protein grazing dormant range. Nebraska Beef Cattle Report, MP 80-A:10.

Lamothe, M., T. Klopfenstein, D. Adams, J. Musgrave, and G. Erickson. 2002. Urinary allantoin as an estimate of microbial protein synthesis. J. Anim. Sci. 80(Suppl. 2):242.

Lardy, G. P. 1997. Protein supplementation of calves and cows grazing sandhills range and subirrigated meadow. Ph.D. dissertation, Univ. of Nebraska, Lincoln.

Lardy, G. P., D. C. Adams, T. K. Klopfenstein, and R. T. Clark. 1999. First limiting nutrient for summer calving cows grazing autumn-winter range. J. Range Manage. 52:317.

Lardy, G. P., D. C. Adams, T. J. Klopfenstein, and H. H. Patterson. 2004. Building beef cow nutritional programs with the 1996 NRC beef cattle requirements model. J. Anim. Sci. 82:E83.

Lardy, G., T. Klopfenstein, D. Adams, J. Lamb, and D. Clark. 1997. Rumen degradable protein requirement of gestating summer calving beef cows grazing dormant native sandhills range. University of Nebraska Beef Rep. MP 67-A:8.

Lintzenick, B. A., R. C. Cochran, E. S. Vanzant, J. L. Beaty, R. T. Brandt Jr., G. St. Jean, and T. G. Nagaraja. 1993. Influence of method of processing supplemental alfalfa on intake and utilization of dormant, bluestem-range forage by beef steers. J. Anim. Sci. 71(Suppl. 1):186.
NRC. 1984. Nutrient requirements of beef cattle. 6th ed. Natl. Acad. Press, Washington, D.C.

NRC. 1996. Nutrient requirements of beef cattle. 7th ed. Natl. Acad. Press, Washington, D.C.

Patterson, H. H., D. C. Adams, T. J. Klopfenstein, R. T. Clark, and B. Teichert. 2003a. Supplementation to meet metabolizable protein requirements of primiparous beef heifers: II. pregnancy and economics. J. Anim. Sci. 81:563.

Patterson, H. H., D. C. Adams, T. J. Klopfenstein, and B. Teichert. 2000. Winter supplementation of primiparous heifers grazing winter range based on the Metabolizable Protein System versus the Crude Protein System. Proc. West. Sec. Amer. Soc. Anim. Sci. 51:61.

Patterson, H. H., T. J. Klopfenstein, D. C. Adams, and J. A. Musgrave. 2003b. Supplementation to meet metabolizable protein requirements of primiparous beef heifers: I. Performance, forage intake, and nutrient balance. J. Anim. Sci. 81:800.

Richards, M. W., J. C. Spitzer, and M. B. Warner. 1986. Effect of varying levels of postpartum nutrition and body condition at calving on subsequent reproductive performance in beef cattle. J. Anim. Sci. 62:300.

Rittenhouse, L. R., D. C. Clanton, and C. L. Streeter. 1970. Intake and digestibility of winter-range forage by cattle with and without supplement. J. Anim. Sci. 31:1215.

Rittenhouse, L. R., C. L. Streeter, and D. C. Clanton. 1971. Estimating digestible energy from digestible dry and organic matter in diets of grazing cattle. J. Range Manage. 24:73.

Rush, I. G., and R. Totusek. 1975. Effects of frequency of ingestion of high-urea winter supplements by range cattle. J. Anim. Sci. 41:1141.

Stokes, S. R., A. L. Goetsch, A. L. Jones, and K. M. Landis. 1988. Feed intake and digestion by beef cows fed prairie hay with different levels of soybean meal and receiving postruminal administration of antibiotics. J. Anim. Sci. 66:1778.

Villalobos, G. 1993. Integration of complementary forage with native range for efficient beef production in the sandhills of $\mathrm{Ne}$ braska. Ph.D. Dissertation, Univ. of Nebraska, Lincoln.

Villalobos, G., D. C. Adams, T. K. Klopfenstein, J. T. Nichols, and J. B. Lamb. 1997. Grass hay as a supplement for grazing cattle I. Animal performance. J. Range Manage. 50:351.

Wallace, J. D., D. N. Hyder, and G. M. Van Dyne. 1972. Salivary contamination of forage selected by esophageal fistulated steers grazing sandhill grassland. J. Range Manage. 25:184.

Wiley, J. S., M. K. Petersen, R. P. Ansotegui, and R. A. Bellows. 1991. Production from first-calf beef heifers fed a maintenance or low level of prepartum nutrition and ruminally undegradable or degradable protein postpartum. J. Anim. Sci. 69:4279. 